\title{
PACIFIST RADICALISM IN THE POST-WAR BRITISH LABOUR PARTY: THE CASE OF E. D. MOREL, 1919-24
}

Edmund Dene Morel was born in Paris in 1873, the son of a French civil servant father and an English mother. Modestly educated in England, he emerged at age thirty from the obscurity of a clerkship in a Liverpool commercial firm to launch a journalistic crusade against the murderous exploitation of blacks on the rubber plantations of the Congo Free State. Largely as a result of this effort he became critical of what he considered the deviousness of the British Foreign Office, and by 1911 he was questioning the extent of the commitment to France in the Entente Cordiale. He was pro-German only in the sense that he opposed the prevalent anti-German hysteria and believed that an Anglo-German confrontation would be catastrophic for both countries. Morel was one of a number of free-trade, anti-imperialist, foreign- and imperial-affairs specialists associated with the pre-war Liberal Party; J. A. Hobson, H. N. Brailsford and E. G. Browne were others. But it was the war which made him the butt of nationalist fury and the victim of government prosecution for his advocacy of a negotiated peace and for his infuriating insistence that Germany's share of the blame for the war's origin was much less than that of Tsarist Russia or even of Britain's Liberal government.

No adequate overall biography of Morel has so far appeared, although several scholars have treated his involvement with the Congo reform movement and the wartime Union of Democratic Control. Marvin Swartz's The Union of Democratic Control in British Politics during the First World War (1971), for example, is an excellent study of the organization which, as executive secretary, he infused with energy and direction. ${ }^{1}$ But the third phase of his career, from the Armistice to his death in November 1924 , has received much less attention. Frustrated and embittered by the

1 On Morel and the Congo reform movement, see William Roger Louis, "The Triumph of the Congo Reform Movement, 1905-1908", in: Boston University Papers on Africa (Boston, 1966), and the introduction to E. D. Morel's History of the Congo Reform Movement, ed. by William Roger Louis and Jean Stengers (Oxford, 1968). 
peace settlement, he devoted himself to a propaganda crusade against it and in favor of those principles of the "New Diplomacy" which the UDC had helped to formulate. ${ }^{2}$ During the war the UDC had provided a close link between the socialist ILP and the anti-war radicals; with the war's end Morel, Arthur Ponsonby, Charles P. Trevelyan, and most of the other radical UDC'ers joined the ILP, and through it the labor movement. Yet the UDC itself continued to exist, constituting a recognizable element in the Labour Party and functioning as the principal source of its foreignpolicy views. It was here that Morel's influence was most evident. In the words of A. J. P. Taylor, "no member of the Labour movement troubled to work out a Socialist foreign policy - if such a thing be possible - so long as Morel was alive." 3 Strictly speaking this is not entirely accurate, for on a number of questions, for instance, the German question, there were alternative views which could be regarded as socialist. The point is, however, that the party generally held to what was basically a radical position, formulated by Morel and others with radical backgrounds.

Morel kept the UDC alive and active in the immediate post-war period in face of the despair felt by many of its wartime adherents, a despair engendered by the khaki election, the military intervention in Russia, and the post-Armistice "hunger blockade" of Germany. In the wake of the Versailles Treaty, representing a massive defeat of UDC principles, he turned out a refurbished and expanded UDC monthly organ, renamed Foreign Affairs. A Journal of International Understanding (the former title was simply The U.D.C.). The first issue (July 1919) contained numerous letters of welcome and expressions of goodwill from trade-union leaders, an admitted tactic to impress workingmen readers. ${ }^{4}$ Contributors to Foreign Affairs were a fairly distinguished lot, many of them with UDC credentials, such as Bertrand Russell. Still it was obvious from the start that the journal was a highly personal vehicle for the expression of Morel's opinions, which were found undiluted in the editorial column, in signed pieces, in bracketed commentaries on the writings of others, and in replies to correspon-

2 The "Six Cardinal Points" of the UDC program, adopted by the UDC General Council on October 17, 1919, were: 1) democratic control of foreign policy, 2) reduction of armaments and the abolition of conscription, 3) the promotion of free trade and the Open Door, 4) national self-determination, 5) democratization of the League of Nations, 6) revision of the peace treaties. See UDC Papers, Hull University (hereafter UDCP), DNC 1/2, October 17, 1919.

3 A. J. P. Taylor, The Trouble Makers: Dissent over Foreign Policy, 1792-1939 (Bloomington, Ind., 1958), p. 135.

${ }^{4}$ UDC, Secretary's Report, October 1919, p. 8; Foreign Affairs (hereafter FA), July 1919. 
dents. Book reviews also served the UDC propaganda line since the editor's selections were made with that purpose in mind. No book received a heartier approbation than John Maynard Keynes's revisionist sledgehammer, The Economic Consequences of the Peace; in fact, the UDC purchased a hundred copies and offered them for resale at a bargain rate. ${ }^{5}$

Keynes's economic analysis became an indispensable weapon in Morel's arsenal of arguments against the 1919 peace terms, arguments which were paraded continuously in the pages of Foreign Affairs. For example, there was the warning that the huge reparations obligation imposed on Germany would have a disastrous impact on the British coal industry, as German deliveries of coal to France were stepped up. But Morel's concern was the morality of reparations, not their feasibility. The moral justification for reparations was the controversial war-guilt clause which Germany had been forced to accept along with all the other peace terms. To Morel, of course, the allegation that Germany was principally responsible for the war was a monstrous lie. In his view, therefore, the only morally justifiable reparations were those to be utilized for the reconstruction of the devastated areas of Northern France and Belgium, where German responsibility was undeniable. All other "indemnities", however, should simply be eliminated, though Britain should attempt to mollify France by forgiving her entire war debt. ${ }^{6}$ Not only Versailles but all of the peace treaties, drafted in the worst wartime spirit of chauvinism, were destined to infect Europe "with a virus of passion and resentment calculated to destroy every attempt at international reconciliation and reconstruction". ${ }^{7}$ Unless they were revised there would be no true peace but, at best, a perpetual state of cold war - "peacewar" was Morel's descriptive term for this in his Foreign Affairs writings. ${ }^{8}$

It is difficult to assess the influence of Foreign Affairs, or even to obtain an exact estimate of circulation figures at any given moment. Morel's contention that it was read in trade-union committee rooms, ILP branches, miners' lodges, co-operative societies, and government offices, as well as in far corners of the globe, such as New Zealand and Togoland, is too vague to be enlightening and cannot be tested. ${ }^{9}$ The only hard evidence is that 12,000 copies per issue were printed in 1923 and 18,000 in $1924 .{ }^{10}$ Whatever

5 UDCP, DDC 1/5, May 11, 1920; FA, June 1920, p. 7.

6 FA, May 1921, pp. 166, 178.

7 Ibid., Special Supplement, February 1920, p. 16.

${ }^{8}$ See, e.g., FA, November 1920, p. 69.

9 Speech typescript, 1923, Morel Papers, London School of Economics (hereafter MP), F

2; Morel to Trevelyan, January 8, 1924, UDCP, DDC 4/30.

10 Morel to the UDC Executive Committee, March 13, 1924, MP, F 6. 
the acceptable figure, it was a small one. Few Labour publications had much of a circulation in these years; most lost money, and Foreign Affairs was no exception. To be sure, it was the only Labour journal to deal exclusively with foreign affairs and was on the recommended reading lists of several trade unions. Since Morel aimed at a working-class readership, he kept the price at an artificially low three pence a copy. Yet at the same time the quality of the writing assumed a fairly high degree of literacy. According to Fenner Brockway, an ILP organizer in the early 1920's, Foreign Affairs circulated among the politically aware, for whom it was a thought-provoking experience as well as a valuable source of information. ${ }^{11}$ Morel tried to broaden this type of appeal by proposing to James S. Middleton, Labour Party secretary, that it serve as the medium for the distribution of Labour Party memoranda on foreign affairs; but nothing came of this approach. ${ }^{12}$

A substantial number of foreigners were among the contributors to Foreign Affairs, most of whom were members of what might be loosely called the UDC "International". After the signing of the peace treaties, with Reaction apparently triumphant, Morel believed that the scattered forces making for a peaceful international society would have to be welded together and infused with a renewed vigor. As the font of doctrinal purity, the UDC would play a role in such a movement analagous to that of the ILP in the British Labour Party. ${ }^{13}$ Morel pushed ahead and succeeded in establishing links abroad with like-minded people, most of whom were liberal-minded, bourgeois intellectuals or distinguished academicians. The renowned Munich economist Lujo Brentano, for example, wrote several articles for Foreign Affairs. One of them, entitled "The Moroccofication of Germany", termed the saddling of Germany with reparations debts a latter-day version of France's penetration of Morocco - inability to pay would be the pretext for territorial aggrandizement. ${ }^{14}$ Brentano's article was typical of those from Continental contributors in its fulminations against the peace settlement and in its demand for treaty revision. Despite the presence of a few French, Italian and American pacifists, the UDC "International" consisted for the most part of Germans, Austrians and Hungarians. Morel also opened the pages of Foreign Affairs to splenetic outcries from treaty-related ethnic minorities, such as the Sudeten Germans; one spokesman, Joseph Korec, lamented the fate of his people

11 Interview with Lord Fenner Brockway, House of Lords, March 17, 1973.

12 Morel to Middleton, March 21, 1921, James S. Middleton Papers, Labour Party Library.

13 Secretary's Report, October 1919, p. 3.

14 FA, March 1921, p. 141. 
under Czech "oppression". ${ }^{15}$ The German contingent of the UDC "International" provided the closest of Morel's foreign collaborators, Count Max Montgelas. As a member of the Reichstag's Committee of Inquiry on the War's Origins and a man with contacts in the German Foreign Ministry, Montgelas was able to furnish him with material on pre-war diplomacy from the German archives; summaries of these findings appeared regularly in Foreign Affairs. ${ }^{16}$

No single issue dominated Morel's thoughts as much as the war-guilt question, or to be more precise, the question of German war guilt - the allegation that the war resulted from a German consipracy. Since this underlay the Treaty of Versailles, he claimed not merely to be dwelling upon the past but highlighting a flagrant injustice currently poisoning international relations and creating conditions for a Second World War. ${ }^{17}$ He was convinced, moreover, that there was an unspoken agreement within the ranks of the Establishment press to ignore the documents published since the end of the war, which shed new light on the subject of war origins: the material from the German, Austro-Hungarian and Russian archives. To counteract this alleged conspiracy of silence, he endeavored to prove, in innumerable Foreign Affairs articles and in a series of pamphlets, that Germany had not plotted a war in 1914. As for Britain's entry into that war, he charged the Liberal government of Asquith and Grey with having betrayed the British people by effectively committing the country to the Franco-Russian alliance. From 1906, according to Morel, the secret military and naval commitment to France had been "the spinal column of our foreign policy", and consequently the Haldane Mission and other efforts to resolve Anglo-German differences had failed, because no formula of British neutrality could be made to square with this obligation. The German invasion of Belgium, though morally inexcusable, served as

15 Ibid., Special Supplement, April 1920, pp. 1-6. The British Minister in Prague rejected Korec's stories as gross exaggerations, Sir George Clark to Sir William Tyrrell, December 8, 1920, Foreign Office Files, Public Records Office, P 1608/1608/150.

16 See, e.g., Montgelas to Morel, February 1, March 22 and 29, April 6, 1920; March 16 and May 17, 1921, MP, F 8; FA, Special Supplement, February 1920, p. 12; July 1921, p. 6. Montgelas also served as one of Morel's chief informants on French occupation policies in the Rhineland. In particular, Morel worked himself up to a fenzy in denouncing the use of African colonial troops and the sexual outrages they allegedly perpetrated on the female population. On the colored-troops issue see Robert $C$. Reinders, "Racialism on the Left: E. D. Morel and the 'Black Horror on the Rhine", in: International Review of Social History, XIII (1968).

17 Morel, Diplomacy Revealed (London 1921), p. x; The Poison that Destroys (London, 1922), p. 25. To his friend Douglas Goldring, Morel predicted that a Second World War would break out in 1939. See Douglas Goldring, The Nineteen Twenties. A General Survey and Some Personal Memories (London, 1945), p. 169. 
an extremely convenient pretext for Britain's declaration of war, convenient because it rallied public opinion against what was presented as totally unprovoked German aggression. ${ }^{18}$

Morel and others in the UDC relentlessly pursued Asquith and Grey. The case against them was not so much that they had concluded an alliance with France, but that they had done so covertly - an open alliance, in fact, conceivably might have had the salutary effect of containing French revanchism, Russian Pan-Slavism, and German militarism. Grey was judged more guilty than Asquith because it was he who had initiated the military connection with France, as Campbell-Bannerman's foreign secretary, but without his full comprehension of the magnitude of the step; Ponsonby, who had been Campbell-Bannerman's private secretary, was absolutely certain of that. ${ }^{19}$ This alleged betrayal of the Liberal Party by its Imperialist wing was of crucial importance to every ex-Liberal now in the UDC leadership. ${ }^{20}$ Of course it was precisely the secrecy of Grey's diplomacy that had furnished the UDC with its cardinal tenet: democratic (parliamentary) control of foreign policy.

Most decidedly, Morel was not a disinterested, dispassionate war-origins investigator. His interest was in exculpating Germany, and his conclusions were structured to do just that. Yet so thoroughly had wartime propaganda done its job that perhaps he could not avoid overstating his case. Notwithstanding his limitations as a scholar - for example, his inability to read German - he was a pioneer of historical research into the causations question, and was recognized as such by the likes of Sidney B. Fay and A. J. P. Taylor. ${ }^{21} \mathrm{He}$ failed, however, in his primary objective of getting the Labour Party to embrace his war-guilt position. Individual endorsements there certainly were, such as that of his old UDC associate Fred W. Jowett at the 1922 annual party conference; ${ }^{22}$ but Morel wanted more than scat-

18 The Secret History of a Great Betrayal (London, 1923), p. 16; The Poison that Destroys, op. cit., pp. 11-13. A recent study, Politicians At War. July 1914 to May 1915 (New York, 1971), by Cameron Hazlehurst, tends to substantiate Morel's judgments. According to Hazlehurst, the waverers in the Liberal Cabinet, such as Lloyd George, Simon, Pease and Harcourt, were kidding themselves when they said that Belgium was the key issue rather than a pretext for the logic of supporting France. Some of these same waverers had previously disputed Britain's obligation to Belgium.

19 Ponsonby to Morel, July 6, 1919, MP, F 8.

${ }^{20}$ Morel was outraged when Lord Haldane, a former Liberal Imperialist, expressed support for the Labour Party and was named Lord Chancellor in the 1924 Labour government. See, e.g., FA, March 1920, p. 4; John Scanlon, Decline and Fall of the Labour Party (London, 1932), pp. 58-59.

${ }^{21}$ Sidney B. Fay, "Mr. Asquith on the War", in: The New Republic, January 2, 1924, pp. 154-55; Taylor, English History 1914-1945 (Oxford, 1965), p. 361.

${ }^{22}$ A. Fenner Brockway, Socialism over Sixty Years. The Life of Jowett of Bradford (1864-1944) (London, 1946), p. 181. 
tered and unofficial support. Undoubtedly he expected the MacDonald government, headed by one of the five founders of the UDC, "to tell the nation the truth as to the past and the present". ${ }^{23}$ Its failure to do so was one of his greatest disappointments, one he expressed publicly in the summer of $1924 .{ }^{24}$ His fixation with the issue simply was not shared by his Labour Party colleagues, not even by those in the UDC; Trevelyan, for one, rightly concluded that it excited little public interest. ${ }^{25}$ Nor did they agree entirely with his interpretation - MacDonald and Leonard Woolf accepted his main thesis that all were guilty, but believed that he underestimated German responsibility. ${ }^{26}$ In the light of the delicate Dawes Plan negotiations of 1924, MacDonald understandably was reluctant to focus attention on an emotional issue such as war guilt, which could hinder the achievement of a Franco-German reconciliation. What Morel evidently did not know, and which might have mollified him somewhat, was that the Prime Minister had decided to publish materials from the British archives relating to the pre-war period, under the editorship of G. P. Gooch and Harold Temperley. ${ }^{27}$

Morel's unsuccessful effort with respect to war origins was only one facet of his propaganda mission to Labour. He worked incessantly to overcome what he considered an abysmal ignorance of the world beyond the parish and the widespread notion that "foreign affairs don't matter". Like the Fabian Society in the domestic sphere, the UDC would provide expert advice and leadership for the unenlightened but numerically significant masses. This instructional endeavor took a variety of forms. Between 1919 and 1921, for instance, two full-time UDC Special Commissioners for Labour, J. W. Kneeshaw and J. H. Hudson, toured England, Wales and Scotland, addressing local Labour parties and trade unions on subjects of international importance and imparting the fundamental message of democratic control. Morel regarded their services highly and always

23 "Europe's Peril. The Danger of Ignorance", in: Saint Mungo, February 1924, p. 3. The other founders of the UDC were Morel, Trevelyan, Ponsonby and Norman Angell.

24 FA, August 1924, p. 31.

25 Trevelyan to Morel, February 29, 1920, Trevelyan Papers, University of Newcastle, CPT 101.

26 MacDonald to Morel, September 3, 1919, MP, F 6; FA, September 1922, p. 70.

27 G. P. Gooch, Under Six Reigns (London, 1958), pp. 270-71. Conservative Foreign Secretary Austen Chamberlain made the announcement in November 1924, after Labour's electoral defeat and after Morel's death. 
regretted the demise of the program in May 1921 for lack of funds. ${ }^{28}$ Kneeshaw and Hudson were the only salaried UDC employees besides Morel and his daughter Stella, who was assistant secretary (she was really her father's private secretary). Another propaganda bridge to Labour was the Foreign Policy Conference, a regional meeting under UDC auspices of the representatives of all local Labour bodies. Next to London, Scotland was the favorite locale for such conferences, where they were usually collaborative efforts between the local ILP branch and the UDC's Scottish Federation under George Aitken. Trevelyan, Charles Roden Buxton and Norman Angell spoke frequently from UDC platforms; and Morel himself almost collapsed from the rigors of a one week's tour in October 1921, which included engagements all the way from Brighton to Newcastle-onTyne. ${ }^{29}$ Such a pace probably contributed to the onset of his first heart attack several weeks later. For more intensive political education than possible within the scope of the Foreign Policy Conference, there was the Holiday School (or Weekend or Summer School, depending on the occasion), "that peculiarly Anglo-Saxon combination of holiday-making, sociability, and more-or-less intellectual effort". ${ }^{30}$ Such "Schools" were very much a part of the social landscape. In the case of the UDC, they provided the opportunity for what could almost be called the training of cadres; men with expertise and experience, such as Norman Angell and Professor H. B. Lees-Smith of the London School of Economics, conducted sessions of young people eager to absorb what they had to offer. ${ }^{31}$

Prominent UDC'ers also operated at higher party conclaves such as the annual conferences. At the 1921 conference in Brighton Morel authored and spoke to a resolution which dissociated the party in advance from any obligation towards foreign states contracted without the approval of Parliament, and urged the Parliamentary Labour Party to sponsor legislation making the validity of future treaties subject to parliamentary approval. He addressed the 1923 conference on behalf of a resolution introduced by MacDonald calling for revision of the Versailles Treaty and de jure recognition of Soviet Russia. Both resolutions received unanimous approval. ${ }^{32}$

28 See, e.g., Morel to Trevelyan, n.d., 1919, Trevelyan Papers, CPT 70; UDCP, DDC 1/5, December 7, 1920, January 13, April 12 and May 24, 1921; Morel to the UDC Executive Committee, March 13, 1924, MP, F 6. For the Reports of the Special Commissioners, see FA, October 1919 - March 1921.

29 Stella Morel to Lees-Smith, November 4, 1921, UDCP, DDC 4/29; Morel to Trevelyan, October 6, 1921, ibid., 4/30.

30 Margaret Cole, Growing Up into Revolution (London, 1949), p. 117.

31 See, e.g., FA, April 1923, p. 219.

32 Labour Party, Report of the Twenty-First Annual Conference, p. 207; Report of the Twenty-Third Annual Conference, p. 223; P. McOrmish Dott to Morel, July 10, 1921, MP, F 8 . 
A more striking example of UDC "permeation" was the composition of the Advisory Committee on International Questions, a body whose main function was the recommendation of foreign-policy positions to the Party Executive. Morel, Ponsonby, Trevelyan, J. A. Hobson, C. R. Buxton, H. N. Brailsford, George Young, H. W. Nevinson, C. Raymond Beazley and other UDC'ers were frequent participants in the committee's deliberations. From July 1922 Morel attended its sessions regularly, acted as chairman on several occasions, and drafted, either alone or in conjunction with one or two others, reports on the war-origins question and treaty revision. The tenor of opinion, not surprisingly, was remarkably similar to that enunciated in UDC councils. ${ }^{33}$ Morel's articles in the journals constituting the Labour press were another means of disseminating the UDC line. For example, a brief piece in The Record, "Why 'Foreign Affairs' are Home Affairs", was an encapsulated version of his major propaganda message to Labour: chronic unemplyment in Britain was a direct outgrowth of the treaty-related economic and political dislocation in Central Europe. ${ }^{34}$

Despite all of his energy and determination, Morel experienced great frustration in his self-proclaimed mission to Labour. The "docility" of the Parliamentary Labour Party under the leadership of J. R. Clynes and other veteran trade unionists often left him exasperated. He was especially angered when Clynes failed to oppose the Lloyd George government on the huge reparations demand on Germany in the spring of 1921, complaining to Labour Party secretary James S. Middleton that he could not understand why the PLP should go its own way on reparations, party resolutions to the contrary notwithstanding. ${ }^{35} \mathrm{His}$ relations with the party's leading trade unionists, fervent "social patriots" during the war, remained frigid; and he also was aware of the continued suspicion of intellectuals among the party rank and file. ${ }^{36}$ "Bourgeois to their fingertips", many UDC'ers exhibited obvious signs of discomfort in their new political home. Taunts of "aristocratic Labour", for example, disturbed the aristocratic Ponsonby; and $\mathbf{J}$. A. Hobson later admitted that he never felt completely at home amid

33 Advisory Committee on International Questions, Minutes and Agenda, Labour Party Library, July 20, September 25 and November 30, 1922; February 22, March 8 and 15, May 3 and 31, July 12, 1923; January 16 and May 28, 1924.

34 The Record, December 1923, p. 7. Morel's articles also appeared in the Daily Herald, Labour Leader, Forward, The Labour Magazine, The Socialist Review, and even in the obscure Saint Mungo.

${ }^{35}$ Morel to Middleton, March 21, 1921. Actually Morel misrepresented Clynes's views on reparations. Although Clynes insisted on Germany's total liability - this is what angered Morel -, he opposed the use of force in securing a settlement and was prepared to see a reduction of the actual sums that Germany would pay. See House of Commons Debates, Fifth Series (hereafter HCD), Vol. 139, cc. 743-44; Vol. 141, cc. 1304-05.

${ }^{36}$ Morel to Montgelas, May 24, 1921, MP, F 8. 
the trade unionists and "full-blooded socialists". ${ }^{37}$ That Morel suffered from the same uneasiness is evident from his near-apology to a Glasgow Labour group in 1923 for having been spared the necessity of earning a living through manual labor, "not through any endowment of mental, moral or physical superiority but through circumstances not for the most part of our own creation". ${ }^{38}$

Such difficulties aside, Morel and other former radicals helped make foreign affairs an important concern of the Labour Party. The scope of their success was limited. As Morel himself conceded, the UDC propaganda effort touched only the fringe of the labor movement - such people as local party leaders, trade-union officeholders, co-operators and other activists. Yet its impact must be measured against the backdrop of previous indifference to other than immediate bread-and-butter issues. In this light Morel's boast in June 1922 that there were two hundred and ninety-four UDC-affiliated Labour bodies with a combined membership of 1,418,075, though not to be taken literally as the number of converts to the cause, is nonetheless an indication of genuine progress. So was the election of eighteen UDC'ers to Parliament in November 1922. ${ }^{39}$ UDC activity peaked during the period between 1919 and 1921 and then began to fade, ironically, with the increasing success of its leaders in politics, a success which made other forums available. Morel justified the organization's continued existence on the ground that it alone concentrated on the prime issues of democratic control, open diplomacy and international co-operation. But the trend was not reversed, if the frequency of UDC General Council and Executive Committee meetings is any index of organizational vitality. The Council met only annually after 1921 as compared to semiannually previously; and the Executive tailed off from weekly sessions in 1919 , to fortnightly and then monthly ones in 1920-21, and to very irregular ones thereafter. ${ }^{40}$

Like many of the other radical recruits to Labour, Morel had had an earlier exposure to parliamentary politics. He had stood for the Birkenhead

${ }^{37}$ Frank Boalcutter to Ponsonby, January 28, 1922, Ponsonby Papers, Bodleian Library, Oxford; J. A. Hobson, Confessions of an Economic Heretic (New York, 1938), p. 126. The leaders of the Stockton ILP cancelled Ponsonby's speaking engagement there when they thought they read that he had greeted royalty, the Queen of Norway. Actually the greeter was his brother Frederick, an aide to George V, but the mistake was indicative of his problem. See Labour Leader, December 4, 1919, p. 2. The "bourgeois to their fingertips" characterization is Fenner Brockway's.

38 Speech to the Glasgow Study Circle, January 21, 1923, MP, F 2.

39 H. M. Swanwick, Builders of Peace, Being Ten Years' History of the Union of Democratic Control (London, 1924), pp. 139, 152.

40 UDCP, DDC 1/1, 2 and 5. 
division from 1912 to 1914 , when he resigned his candidacy over the Liberal government's declaration of war. In 1920, however, he decided to contest Dundee, an industrial city in Eastern Scotland, a choice that was not at all fortuitous. For Dundee was "the seat of the War Lord", Winston Churchill, whose bellicose public posturing and passionate imperialism epitomized what Morel hated most in British political life. Most recently, as War Secretary in Lloyd George's Coalition Cabinet, Churchill had been the most ardent exponent of intervention in the Russian Civil War. In Morel's totally uninhibited opinion, Churchill was an "ambitious militarist whose perpetual errors of judgment, intemperateness of expression and invincible incapacity to learn, render him more fit for a strait-waistcoat than for Cabinet responsibility". ${ }^{41}$

Morel spoke periodically in Dundee on behalf of his candidacy. His overall strategy was to relate his foreign-policy views to issues of concern to Dundee voters. He made the point, for example, that lagging employment in the locally important jute industry was caused by the decline in sales of jute bags to Russia, which in turn was the result of the Coalition government's unwillingness to restore normal Anglo-Russian relations. ${ }^{42}$ Even in speeches devoted to basic economic issues, he managed to bring in his pet theme of democratic control. Foreign-policy decisions, he maintained, could profoundly affect the price of food and governmental allocations for housing and social-welfare measures; yet such decisions were not subject to effective popular control. ${ }^{43}$

The election campaign in the fall of 1922 was a tumultuous one, degenerating at times into a contest in defamation of character. While Churchill lay temporarily incapacitated after an emergency appendectomy, several surrogates, most notably his wife and his friend and erstwhile colleague in the defunct Coalition Cabinet, Lord Birkenhead, carried on for him. They maligned Morel as a crypto-Communist and charged that his semi-foreign origin and wartime prison term reflected unfavorably on his patriotism. ${ }^{44}$ Churchill himself recuperated in time to repeat the same allegations; Morel, he claimed, was "a consistent, conscientious, and sincere friend of Germany, and a consistent, conscientious, and sincere enemy, or, at any rate, an indifferent acquaintance of Britain". ${ }^{45}$ Such lies

41 FA, December 1920, p. 86.

42 Ibid., November, p. 84.

43 See, e.g., "Labour's National Ideal", January 24, 1921; "British Labour and the Problem of Empire", January 26; "The Co-operative Movement and World Problems", January 27, MP, FA.

44 Dundee Advertiser, October 30, 1922, p. 4; November 10, p. 5.

45 Ibid., November 15, p. 5. 
and innuendoes, Morel replied, were a sign that "the pocket Napoleon seemed to see before him a Waterloo". Name-calling was a double-edged sword, he warned, as he recalled to the delight of his audience that there were unsavory things in the Churchill family history. As for Birkenhead, who had played to British xenophobia by making an epithet of the Labour candidate's full original French name - Georges Edmond Pierre Achille Morel-de-Ville -, he was credited with "a third rate music hall performance", one suited to the talents of that "ex-apostle of mob rule" and "fomenter of open rebellion". 46 of the six candidates standing in the two-member constituency, Churchill came in fourth, nearly 10,000 votes behind Morel, who came in second (behind a local prohibitionist) and thus secured one of the two seats. ${ }^{47}$ The propagandist of the written word had successfully transferred his skills to the political hustings, aided by a powerful voice and an imposing physical presence which, except for his greater stature, was not unlike that of Scotland's own Ramsay MacDonald. ${ }^{48}$ Yet it would be an error to separate the Dundee result from the general electoral trend. Depressed economic conditions throughout the nation, but especially in the industrial North, contributed to Labour's gain of eighty seats. Under such circumstances the party's domestic program could not help but appeal to large numbers of Dundee voters, and Morel presented it effectively if unorthodoxly.

Morel soon emerged in the House of Commons as one of the Labour party's leading spokesmen on foreign affairs, as a result of which - and because he was the notorious Morel - he suffered taunts of pro-Germanism from the ranks of the Tory "Die-Hards". Since he was consumed by the question of justice for Germany, the 1923 French invasion of the Ruhr naturally seemed to him a nightmare become reality. In a speech of February 16, characterized by an unfriendly Labour MP as "vigorous, rude eloquence", he denounced it as "morally indefensible, legally indefensible, inimical to our national interests and peace". ${ }^{49}$ It was pointless, he argued, to announce opposition to the occupation, as the Tory government had done, and then stand aside and allow it to take place unhindered; such a policy could only serve to sustain French militarism. He suggested instead

46 Ibid., November 10, p. 6 ; November 11 , p. 8 . Before the war Birkenhead had been outspoken on behalf of the Ulster Unionists and their determination not to accept Home Rule.

47 Ibid., November 16, p. 3; November 17, p. 5 .

48 Morel stood six feet tall, and had broad shoulders, a well-groomed mustache, silver hair and large dark eyes.

$49 \mathrm{HCD}$, Vol. 160, cc. 521, 536. The unfriendly MP was James Sexton, general secretary of the National Dock Workers and one-time president of the TUC. Sexton had been violently hostile to the UDC during the war. 
that Britain openly repudiate the Versailles policy of vengeance by condemning France's use of force in the Ruhr and her separatist schemes in the Rhineland, and by renouncing the British share of reparations. Britain should also take the lead in convening a special international conference which would be empowered to re-examine and revise the peace treaties; after its successful conclusion she should join in a general guarantee of the Franco-German border. ${ }^{50}$ The last point touched on the French obsession with security, which Morel regarded impatiently as a spurious issue. France, he asserted, already possessed what amounted to overkill - sixty million Germans faced not forty million Frenchmen, as claimed, but a combined total of one hundred million French, French colonials and East European auxiliaries. On May 10, in the midst of another debate on the Ruhr crisis, he accused France outright of organizing the new Europe for war through munitions loans to Poland and the countries of the Little Entente, and through military alliances with them, concluded or in the offing. 51

The Labour Party's official position on the Franco-German question was identical to Morel's. In fact, he was instrumental in drafting a resolution, passed at the 1923 annual conference, which called for the limitation of reparations to the devastated areas of France and Belgium; the reconsideration of the war-debts question, as part of a settlement of the reparations problem; the immediate withdrawal of Allied armies from all German territory; and the convoking of a world conference to revise the peace treaties. ${ }^{52}$ Within the ranks of the party, however, there were extreme socialists who resented the ex-Liberals and their emphasis on foreignpolicy questions. Four Clydesiders - James Maxton, John Wheatley, David Kirkwood and Campbell Stephen - after returning from a visit to the Ruhr in February 1923 advocated some form of international control for the region. Nor could they understand the fuss about the sufferings of people in Central Europe; for one thing, housing conditions in Glasgow were far worse than anything they had observed in Germany. At the 1923

50 Ibid., cc. 528-29.

51 Ibid., Vol. 163, cc. 2673-76. Morel wrote in the March 1923 FA that the important question was not security for France, but security for Europe "against the recrudescence of a Napoleonic militarism with resources in men and raw materials which Napoleon never dreamed of in his wildest moments". The danger of "French militarism" was not such an outlandish idea in the early 1920's. France had the largest military establishment in Europe, including the largest airforce, and Britain and France had come close to a confrontation over the Chanak episode in September 1922. There was a growing distrust of France along the entire British political spectrum, with the exception of the Conservative "Die-Hards" whose Germanophobia remained fully intact.

52 Report of the Twenty-Third Annual Conference, pp. 221, 223. 
ILP annual conference Wheatley read into the concern of the party's internationalists with the Ruhr a willingness to put pressure on France that might lead to war, a war to decide whether French or German capitalists should control the Ruhr. He also rejected their pet theory that political turmoil in Europe was primarily responsible for unemployment in Britain. ${ }^{53}$ Morel could only reassert his belief that the kind of total absorption in domestic affairs characteristic of the Clydesiders was foolishly shortsighted. Along with H. N. Brailsford, editor of the New Leader, he fought back by persuading the Advisory Committee on International Questions to denounce the statements of Wheatley and the others as contrary to party policy. ${ }^{54}$ Nevertheless such statements were highly embarrassing to those who prided themselves on educating the labor movement. Outcries of indignation from the UDC's German friends, for example, led Ponsonby to reassure Montgelas that the Labour Party as a whole would continue its efforts along the usual lines. ${ }^{55}$

Morel himself was one of the many foreigners to visit Germany during the Ruhr crisis, for several weeks during September and October 1923. In Munich he conferred with Bavarian Social Democratic and trade-union leaders, and also with a few rightists, most notably Gustav von Kahr (soon to play a conspicuous role in Hitler's attempted Beer Hall Putsch). His advocacy of a better deal for Germany attracted much favorable attention; but more sobering for Germans was his warning that armed resistance to France would be folly and that the anticipation of armed support from Britain was even greater folly. ${ }^{56}$ From Munich Morel travelled to Berlin, where he had an interview with Stresemann. Although there is no record of their remarks, the Chancellor's ability obviously impressed thim. He argued, with perhaps more foresight than he was cognizant of, that Stresemann was the only man who could save the German Republic. ${ }^{57}$

On October 20, shortly after his return from Germany, Morel had a private meeting with Prime Minister Stanley Baldwin at Chequers. He related his talks with Stresemann and other German political figures, and

53 Robert E. Dowse, Left in the Centre: The Independent Labour Party, 1893-1940 (London, 1966), pp. 96-97. Ironically it was the UDC'er Hobson who supplied Wheatley with an explanation for chronic unemployment in Britain - the theory of underconsumption.

54 Advisory Committee, Minutes, February 22, 1923.

55 Montgelas to Ponsonby, April 18, 1923, Ponsonby Papers. Montgelas felt reassured: "The speeches of Snowden, Buxton and Morel amply prove that all is being done what is practically possible under prevailing circumstances".

56 See especially Robert H. Clive, Consul General in Munich, to the Foreign Secretary, October 26, 1923, Foreign Office Files, C 18645/347/18; also Morel to Ponsonby, September 6, 1923, January 25, 1924, UDCP, DDC 4/10.

57 FA, November 1923, p. 83. 
tried to impress upon Baldwin the need for a stronger Britsh initiative with respect to the convoking of an international conference on the Ruhr. Baldwin was affable enough but non-committal. ${ }^{58}$ More significant than this tête-à-tête was Morel's defense of Stresemann, leader of the antisocialist, big-business German People's Party, against the suspicions of the Labour Left. Writing in The Labour Magazine, he pointed out that continued disruption and chaos in Germany almost inevitably would mean the annihilation of the Social Democratic Party as well as all other democratic elements in German society. Saving Germany from collapse, therefore, was not only a question of simple justice and decency, but crucial for the survival of the largest party in the international socialist movement. He argued that it was the height of doctrinairism for foreign socialists to heap abuse on the Stresemann coalition government, which was the only possible one under the present circumstances and was supported by the German Social Democrats themselves. ${ }^{59}$

Morel always rejected the class conflict as the basis for evaluating international relations. He had no patience with the view of some on the British Left that no just international order could coexist with capitalism. For him the German question was a case of monumental injustice (the Versailles Treaty) resting on a great lie (the allegation of Germany's sole war guilt). He wanted nothing to detract attention from what he regarded as the outstanding moral issue of his age. Though not deeply knowledgeable about German internal politics, he did say many times that Allied harshness towards the new Germany could only aid the revanchist Right. His defense of Stresemann was entirely consistent with his general outlook. And when reporters for the Daily Herald characterized plans afoot to stabilize the German economy as designs to salvage the "bourgeois dictatorship", he penned a strong protest to the paper's editor, Hamilton Fyfe ${ }^{60}$ Morel's focus was undoubtedly narrow. He never addressed himself to the question of illicit German rearmament, except to say that a nation kept in bondage by an unjust treaty would always conspire to break that bondage. With essentially the same argument he seemed to excuse, or at least to explain away, the assassinations of Rathenau and other repu-

58 Memorandum, Saturday, October 20, 1923, MP, F 7.

59 "The Disruption of Germany. A Catastrophe for International Labour", in: The Labour Magazine, November 1923, pp. 300-01. The Social Democrats dropped their support of Stresemann when he sent troops to oust the Socialist-Communist governments in Saxony and Thuringia. Morel, however, did not change his tune.

60 Morel to Trevelyan, October 21, 1923, Trevelyan Papers, CPT 105. Examples of such articles can be found in the Daily Herald, December 17, 1923, p. 1; December 27, p. 4; February 1, 1924, p. 3; February 5, p. 3. Apparently, then, Morel's remonstration had little effect. 
blicans as pathological manifestations of the resentment against intolerable foreign oppression. ${ }^{61}$ The murderous determination of the Right to destroy the new Republic; the unrelenting militarism; the enduring power of the trusts; the virulent antisemitism - all were features of German political life overlooked by the former crusader against barbarism and war.

The Ruhr crisis undermined much of Morel's faith in what he called the International Labour Movement. In his opinion, it had failed dismally as a force for international sanity. The passions of nationalism had triumphed, as in 1914; otherwise, how could one explain the acquiescence of the labor movement outside Germany in France's punitive measures. ${ }^{62}$ Nor was he optimistic about the League of Nations; for without the participation of Germany, Russia and the United States it was a "victors" club", harnessed to the Treaty of Versailles and sanctioning its "lawlessness". ${ }^{33}$ Some day there might be a League of Nations worthy of the name; but for the immediate future the "great international healing instrument" could only be the United States. Nearly all of Morel's pronouncements on the Ruhr contain references to the indispensability of American participation in future negotiations; and successful revision of the peace settlement, he believed, hinged entirely upon close Anglo-American collaboration. For the realization of these hopes, he counted on a rebirth of Wilsonianism in America. Wilson's ideals, frustrated at Paris in 1919, were precisely those of the UDC. Now he was gone, but Morel refused to be disheartened. His faith was sustained, for example, by William E. Borah of Idaho, a power on the Senate Foreign Relations Committee, whose views on European affairs read like a Morelian manifesto: "instant revision" of the Versailles Treaty and an end to secret diplomacy, among other things. ${ }^{64}$ Borah's name figured prominently in Morel's journalistic commentary, and the two men exchanged letters early in 1923, Borah declaring that he found himself "quite in agreement" with Morel's opinions. ${ }^{65}$

Once implanted, Morel's confidence in America and Americans was highly resistant to assault. He minimized unpleasant aspects of American

61 FA, August 1922, p. 26.

62 "The Disruption of Germany", loc. cit., p. 301.

63 FA, October 1923, pp. 70-71. As an internationalist, of course, Morel endorsed the principles of the League. In fact, his brand of internationalism went much further by encompassing such things as international control of scarce natural resources and aid for underdeveloped, non-European countries.

64 See, e.g., Marion McKenna, Borah (Ann Arbor, Mich., 1961), pp. 165, 186-88, 218.

65 Morel to Borah, n.d.; Borah to Morel, January 17, 1923, William E. Borah Papers, Library of Congress. Morel also was gratified by the scholarship of American historians, particularly Sidney B. Fay, on the war-origins question, affirming his contention that Germany's was not the sole guilt. See, e.g., his letter "Reparations and War Guilt", in: Nation and Athenaeum, August 4, 1924, p. 589. 
life, such as rampant materialism and political scandal, and also on-thescene reports by UDC colleagues - J. A. Hobson's, for instance, noted the absence of an American spirit of internationalism. The American people, he insisted on believing, possessed "an instinctive humanism" destined to become "the most powerful constructive influence for good in the world". ${ }^{66}$ As his own modest effort to help revive Wilsonianism, Morel sent a number of appeals to leading American newspapers and journals in 1923 and 1924. In highly moral terms he called upon the United States to work for the pacification of Europe and thereby rectify the wrongs that its military intervention had made possible. ${ }^{67}$ An interventionist America, along Wilsonian lines, seemed remote in the early 1920's. Yet Morel was correct in seeing that without the power of the United States there could be no stable world order based on liberal principles. Whether there ever could be such a world order is something else again, but his entire being revolved around the dream of one. Undeniably Europe floundered without the wealth and prestige of the United States - what else was the Dawes Plan but a massive injection of both into a debilitated political and economic structure? Morel's arguments in favor of Anglo-American co-operation, interestingly enough, partook of the same balance-of-power concept which he had denounced so vehemently in connection with the events leading to the World War. On one occasion he declared that the British Empire could only survive "if we do establish a broad, unfettering understanding with America". ${ }^{6}$

Though far from embracing the Wilsonian mission, the United States did seem to be moving towards a more active role in European affairs by the end of 1923. This, together with the Labour victory in the general election of December, made Morel more optimistic about the furture than at any time since the signing of the Treaty of Versailles. But the last year of his life - he was to die in November 1924 - may have been the most frustrating of all. Labour's electoral triumph, for example, failed to bring him the anticipated cabinet- or sub-cabinet-level appointment. A strong sense of personal antipathy had always pervaded the relationship between him and Ramsay MacDonald, the party's leader. During the war they had worked

${ }_{66}^{66}$ FA, December 1921, pp. 83-84. For Hobson's opinions see ibid., May 1920, pp. 7-8. ${ }^{67}$ See especially "An Appeal for Anglo-American Co-operation", in: The Freeman, February 6, 13 and 20, 1924, pp. 513-14, 537-38, 560-62.

${ }^{68}$ FA, Special Supplement, December 1921, p. 7. Views almost identical to Morel's about the need for American participation in international affairs and Anglo-American co-operation were being voiced by a number of prominent Britons, most notably, by Lloyd George. See, e.g., the accounts in the New York Times of his October 5 November 3, 1923, speaking tour of the United States and Canada. 
together in the UDC Executive Committee, though not without considerable friction; but since then MacDonald had allowed his ties to the UDC to lapse. According to Ponsonby, who was close to both men, Morel's expertise in foreign affairs and his quality of personal magnetism excited MacDonald's keen jealousy. ${ }^{69}$ More to the point, the latter's quest for political respectability made him wary about being identified with the kind of drastic treaty revisionism represented by Morel. ${ }^{70}$ Morel, in turn, was becoming increasingly suspicious of MacDonald's tendency towards compromise and vacillation. ${ }^{71}$

J. A. Hobson later wrote that when Morel was not included in MacDonald's first government "no surprise was felt by those who understood their relations". ${ }^{72}$ For Morel, however, his exclusion was unexpected and painful. After all, MacDonald detested Philip Snowden too, but there was no thought of questioning his bona fides for office. The reminiscences of Hobson and of Morel's friends, such as feminist Helena M. Swanwick and novelist Douglas Goldring, all attest to his anticipation of an appointment; ${ }^{73}$ and Morel, though discreet, gave evidence of it in various ways. His American friend, Albert Jay Nock, editor of The Freeman, reported with an insider's assurance "that he is to hold an important position in the Foreign Office under the new Government". ${ }^{74}$ A poignant, though unverifiable, indication of his expectation of office was the subject of an unsigned piece in the Daily Sketch of November 17, 1924, five days after his death. The writer testified that a journalist friend of his had received a telephone call from Morel eleven months earlier inquiring whether he wanted an interview with Labour's first foreign secretary. ${ }^{75}$

Morel would have preferred the Foreign Office, but he would have been content with the Colonial Office, or even with an undersecretaryship in either of those departments. ${ }^{76}$ None of these came his way. Clifford Allen,

${ }^{69}$ Memoir of E. D. Molel, Ponsonby Papers. According to Hamilton Fyfe, Morel's 1922 election victory in Dundee brought not a word of congratulation from MacDonald. See Hamilton Fyfe, My Seven Selves (London, 1935), pp. 255-56.

${ }^{70}$ See, e.g., MacDonald to Ponsonby, August 20, 1922, Ponsonby Papers. Morel's name was not mentioned, but MacDonald's condemnation of the continuous expression of anti-French sentiment in the Labour camp had to mean him more than anyone else.

71 "All right on home affairs, but no strong lead on international affairs, I regret to say", was Morel's comment on a MacDonald campaign statement of November 1, 1923. See Morel to Trevelyan, November 1, 1923, UDCP, DDC 4/30.

72 Hobson, Confessions of an Economic Heratic, op. cit., p. 106.

${ }^{73}$ Hobson, "Comment on Morel's Death", in: The Nation (New York), December 3, 1924, p. 600; H. M. Swanwick, I Have Been Young (London, 1935), p. 374; Goldring, The Nineteen Twenties, op. cit., p. 161. See also Fyfe, My Seven Selves, op. cit., p. 256.

74 The Freeman, February 6, 1924, p. 508.

${ }^{75}$ Cutting from the Daily Sketch, November 17, 1924, MP, F 1.

${ }^{76}$ So he told Douglas Goldring (The Nineteen Twenties, p. 161). 
chairman of the ILP and a close associate of MacDonald's, explained to a group of ILP people remonstrating over Morel's failure to get the Foreign Office, which MacDonald took for himself, that Britain's chief negotiator in the talks pending with France over the Ruhr and reparations could not be somebody with a flagrantly anti-French image. ${ }^{77}$ To this difficulty Allen could have added the problem posed by Morel's past criticism of highranking Foreign Office professionals as practitioners of secret diplomacy and their disdain for him as a troublemaker. These handicaps, however, would have been much less operative in a subordinate post, and therefore an additional rationale had to be concocted. This was forthcoming from MacDonald himself, who wrote to Morel that his own earnest efforts to find an undersecretaryship somewhere had encountered the unshakable opposition of other department heads. ${ }^{78}$

MacDonald's explanation was not patently false. As Sidney Webb believed, the trade unionist and wartime social patriot J. H. Thomas (considered an ignorant chauvinist in UDC circles) may have strenuously refused to have Morel under him at the Colonial Office; but MacDonald himself was "head" of the Foreign Office. Webb was certain that some expedient could have been found had the desire been present. ${ }^{79}$ If MacDonald could defy party opinion over the appointment of the Conservative Lord Chelmsford to the Admiralty, and of Lord Haldane, the former Liberal Imperialist, to the Lord Chancellorship, then he could have defied the few right-wing trade unionists who might have protested Morel's inclusion at the secondary level. But he was not so much concerned with party opinion as he was with the public's opinion of the party. Appointments such as Chelmsford's and Haldane's would convey respectability and help to expunge the party's red image, and so would the exclusion of men with reputations as extremists. The quest for Labour respectability was understandable from the standpoint of a minority government consisting of men regarded by a large part of the electorate as firebrands. However, it manifested itself in near absurdities such as the tempest over the refusal of several ministers to wear court dress and in the classes in deportment for new Labour MPs. In such a climate, as Bertrand Russell

77 Arthur Marwick, Clifford Allen. The Open Conspirator (Edinburgh and London, 1964), p. 86. Marwick's source for this information was Miss Minnie Pallister, a member of the pro-Morel group. Unquestionably Morel was hated by the French Right. For example, he was viciously attacked in the semi-official Mercure de France by Jean Maxe, in a piece entitled "Le défaitisme de la paix en Angleterre. J.-M. Keynes et E.-D. Morel", November 1, 1923.

78 MacDonald to Morel, n.d., but probably early February 1924, MP, F 2.

79 Sidney Webb, "The First Labour Government", in: The Political Quarterly, XXXII (1961), p. 17. 
later observed, it would have been unrealistic to think that MacDonald would include in his government "anyone so tainted with pro-Germanism as Morel". 80

A good many UDC'ers were in the new government, notably Ponsonby as Undersecretary for Foreign Affairs and Trevelyan as President of the Board of Education; and this chagrined Morel more than anything else. Writing to MacDonald, he complained that his exclusion could only lend credence to the worst charges and innuendoes against him, that he was somehow "smirched". ${ }^{81}$ Although MacDonald hinted at the possibility of a future appointment, it never materialized; Morel's own proposal that a new post, that of Parliamentary Secretary for the League of Nations, be created for him was rejected by the Foreign Office as being "anomalous". 82 His only tangible reward for services to the party was an appointment to the Executive Committee of the Parliamentary Labour Party, which was intended to serve as a liaison between the PLP and the Labour cabinet. Included on the Committee were George Lansbury, Thomas Johnston, Richard Wallhead, James Maxton and others on the Labour Left, who would subsequently subject Labour ministers to grueling interrogations and tongue-lashings. Another gesture by the party leadership, the nomination of Morel for the 1924 Nobel Peace Prize (citing his career as justification), was soiled from the start by the sarcasm and ridicule with which it was greeted in much of the daily press. The Tory leader writers particularly enjoyed pointing out the irony in the fact that the Nobel nominee was persona non grata in his own party when it came to a ministerial appointment. ${ }^{83}$ Nor was the prize itself a consolation, since none was awarded that year.

Morel's sense of personal rejection soon fused with a growing disquiet over the MacDonald government's apparent indifference to some of the most cherished planks in the UDC platform. The party had clearly endorsed the most sacrosanct of all UDC tenets, democratic control of foreign policy; and even during the depths of his depression over exclusion from office Morel remained confident that he would be permitted to ${ }^{80}$ The Autobiography of Bertrand Russell, II (London, 1968), p. 39.

${ }^{81}$ Morel to MacDonald, excerpted in a letter from Morel to Lord Parmoor, February 2, 1924, MP, F 2.

${ }^{82}$ Morel to Lord Parmoor, ibid.; Ponsonby to Morel, Febrary 1, 1924, MP, F 2.

${ }^{83}$ The Times, January 31, 1924; Morning Post, January 31; Evening News, January 31 . A number of French and Belgian newspapers commented unfavorably on Morel's nomination. The British Minister in Brussels reported that the MacDonald government was being attacked by the right-wing press for its role in honoring the man who had slandered Belgium over the Congo and minimized her wartime victimization by the Germans. Charles Wingfield to the Foreign Secretary, February 7, 1924, Foreign Office Files, W $107 / 820 / 4$. 
introduce on the floor of the House of Commons the following resolution drafted by the UDC Executive Committee (with MacDonald's concurrence):

That, in the opinion of this House, no diplomatic arrangement or verbal or written understanding with a foreign State, involving, even indirectly, military obligations, shalr be finally concluded without the consent of Parliament, and no preparations for co-operation in war between the naval, military, or air staffs, and the naval, military, or air staffs of a foreign State shall be lawful without Parliamentary sanction, and this resolution shall be communicated to all States with which we are in diplomatic relations and to the League of Nations. ${ }^{84}$

A month's time passed without any government initiative on the question of democratic control, much to Morel's frustration. But on April 1 Ponsonby, now Undersecretary at the Foreign Office, announced in Parliament that henceforth any treaty, including "agreements, commitments and understandings by which the nation may be bound in certain circumstances", would lie on the table of the House of Commons for twenty-one days after signature, after which the document in question would be considered ratified. It would then be circulated in the House. During the twenty-one-day period, any MP would have the opportunity to initiate a debate on the treaty by applying through the usual channels. These procedural changes, said Ponsonby, represented the government's determination to make secret treaties and secret clauses impossible. ${ }^{85}$

Morel was not satisfied with this declaration, though he praised it as a first step. He still insisted on a bill, or at least a resolution, a measure that would bind not only the present government but future ones as well. ${ }^{86}$ The government, however, would go no further. Ponsonby pointed out to his friend that a bill would be "truly devilish", take a whole session, and be "ridden by constitutional lawyers". Moreover, since there was little interest in the question in Parliament, and even less in the Cabinet, his April 1 statement had really accomplished all that was feasible at present. ${ }^{87} \mathrm{Morel}$ responded to Ponsonby's unreceptiveness by asking his other UDC intimate, Trevelyan, to intercede at the Cabinet level. ${ }^{88}$ Although Trevelyan's department, Education, was a domestic one, he continued to display interest in foreign affairs. His immediate response to Morel's plea is not

${ }^{84}$ Quoted in Swanwick, Builders of Peace, op. cit., p. 170. See also Morel to Lord Parmoor, February 1, 1924.

85 HCD, Vol. 171, cc. 2003-05.

86 Morel to Ponsonby, April 4, 1924, MP, F 2.

87 Ponsonby to Morel, April 5 and 19, 1924, MP, F 2.

88 Morel to Trevelyan, April 30, 1924, Trevelyan Papers, CPT 108. 
clear since his reply, if written, is not available. But perhaps it is significant that he later took it upon himself, in March 1925, to re-introduce his late friend's resolution in the House of Commons.

Morel introduced his resolution on May 22, 1924, despite Ponsonby's warning that the accumulation of parliamentary business precluded a day for its consideration. Clynes, the Leader of the House of Commons, did indeed turn down his request for debating time on grounds that no time could be diverted from that needed for the consideration of proposed social legislation. ${ }^{89}$ Nevertheless Morel persevered, winning endorsement of his resolution from the PLP and its Executive Committee, the Trade Union Section of the PLP, the ILP, the Advisory Committee on International Questions, the Daily Herald and the New Leader. ${ }^{90}$ Probably at his instigation, several ILP and UDC branches sent resolutions to every Cabinet member, expressing regret over the government's refusal of debating time. ${ }^{91}$ The issue also surfaced at the Labour Party's annual conference held in London on October 7-10. Samuel Elsbury of the Tailors and Garment Workers Union strongly criticized the government's inaction; and more significantly, the party's National Executive Committee and the PLP's Executive agreed to empower a delegation to call on MacDonald and urge him to provide time in the current parliamentary session for Morel's resolution. ${ }^{92}$

Yet however impressive Morel's support on paper, the issue of democratic control simply did not generate enough political heat to pressure the government into altering its attitude. Perhaps the joint National Executive-PLP deputation to the Prime Minister, had it materialized, would have had some effect; but the parliamentary session, and the Labour government itself, ended on October 8 with a confidence-vote defeat on the Campbell Case. Morel would die on November 12 with his resolution in a state of limbo. To his old UDC associates in the Labour government, a parliamentary resolution on democratic control was a tactical question. Ponsonby described it as inexpedient, employing arguments which on their face were highly plausible. From Morel's viewpont, however, the rebuff to him was part of a general, and deplorable, pattern of Labour temporizing. Undoubtedly too, the government's refusal of what seemed to him a small

$89 \mathrm{HCD}$, Vol. 174, cc. 1059-60.

90 Advisory Committee, Minutes, July 23, 1924; FA, June 1924, p. 249; September, p. 52.

${ }^{91}$ FA, July, p. 22; J. M. Fells to John Wheatley, MP, June 5, 1924, Foreign Office Files, W 4828/4828/50; Ilford Branch ILP to the Foreign Secretary, June 13, 1924, ibid., W $5000 / 4828 / 50$. The Foreign Office minute commented that the letters seemed to be part of a "plot", or "concerted plan".

92 Report of the Twenty-Fourth Annual Conference, pp. 56, 120, 143. 
favor - a day for the debate of a UDC-inspired resolution - appeared to him as another manifestation of that outrageously contemptuous behavior that MacDonald had exhibited towards him at the time of the government's formation.

More troubling still was MacDonald's abandonment of the Labour Party's uncompromising anti-French stance. His letter of February 4 to Premier Poincaré, expressing the hope that the Entente would be much more than a nominal thing, seemed to sound the retreat, as did his disavowal in the House of Commons on February 27, of a recent statement by Home Secretary Arthur Henderson calling for revision of the Treaty of Versailles. ${ }^{93}$ For a time Morel maintained a façade of public loyalty to the government; but by late March he could no longer contain his growing doubts. MacDonald's policy was in the right direction, he wrote in Foreign Affairs, "in so far as it can be judged by material publicly accessible". He especially regretted the government's failure so far to begin the indispensable process of "intellectual sanitation (clearing away the lies of the past five years)", and that the Franco-German problem was still being presented as one of how to wring more out of Germany and ensure French security.$^{94}$ In retrospect, it appears that MacDonald's chief failing was not his understanding of the realities of the European situation but his inability or unwillingness to communicate with members of his own party. Had he tried to implement official Labour Party policy, he would have been forced to launch a moral crusade against France; and such a crusade would have ruined whatever chance existed for a resolution of Europe's problems. As it was, his diplomatic skill had succeeded in lessening French hysteria. At home, however, the skilled diplomat was the largely unapproachable party leader. "J.R.M. is impossible to reach", Ponsonby remarked not long after entering office as his subordinate at the Foreign Office. ${ }^{95}$ Years later Ponsonby recalled MacDonald's attempts to stifle intra-party criticism, his disdain for former colleagues and friends, and his violation of party pledges "in order to toe the line as a conventional government". ${ }^{66}$ The psychological shock that his behavior produced on many in the UDC circle was profound. Almost a year later an article entitled "The Diplomacy of Mr. Ramsay MacDonald" appeared in The Labour Monthly, authored by someone using the pseudonym "U.D.C." So startling was the retreat from the party platform, according to "U.D.C.", that few realized immediately what was happening; and it was pitiful to behold the spectacle of men like

93 The Times, February 25, 1924, p. 7; HCD, Vol. 170, c. 610.

${ }^{94}$ FA, April 1924, pp. 193-94.

${ }^{95}$ Ponsonby to Morel, February 1, 1924.

96 Memoir of J. Ramsay MacDonald, Ponsonby Papers. 
Morel trying, "until further trying was impossible, to persuade themselves that it was not so". .7

A denouement of the whole reparations issue seemed at hand when the Dawes Committee of experts produced its report on April 9, a report soon accepted by Germany and her creditors as the basis of a reparations solution. Morel gave it a tentative approval on the ground that anything was better than the present unendurable crisis situation. But he reminded his Foreign Affairs readers that reparations rested on the historical falsehood of German war guilt, and that the Dawes Plan, which placed no limits on Germany's total liability, meant that the "tribute paying" would continue indefinitely. ${ }^{98}$ The UDC Executive Committee, presided over by Morel, subsequently criticized the plan as "morally wrong", "politically unwise" and "economically disastrous", and argued that if it were to have any chance of success the following proposals would have to be included in the settlement package: 1) that all signatories pledge themselves not to take independent action in the event of a default; 2 ) that Britain renounce any further share in reparations; and 3) that Germany be admitted to the League of Nations on the basis of perfect equality. ${ }^{99}$

The statement of the UDC Executive was a source of embarrassment to the Labour government, as the Conservative Daily Telegraph was quick to point to "the intimate line connecting the Union with the most influential circles in the Labour Party". ${ }^{100}$ There also was the fear, expressed by Ponsonby, that the German Nationalists, who were vehemently opposed to the Dawes Plan, might make political capital out of the UDC's critique, and also that French suspicions of Britain might become exacerbated. Therefore, he informed Morel, he had felt compelled to issue a statement describing the UDC as an entirely private body, in no way connected with the government; and he had requested Trevelyan and other government ministers to cancel their UDC ties "so that if questions are asked we may truthfully say that no member of the Government is on the UDC". ${ }^{101}$ This exchange was not the first instance of intra-party controversy over the Dawes Plan; Morel had confronted MacDonald directly at a meeting of the PLP Executive Committee not long after the publication of the experts' report. According to one observer, the vitriolic "U.D.C.", Morel inquired

97 "U.D.C.", The Diplomacy of Mr. Ramsay MacDonald, p. 7. This article, which first appeared in The Labour Monthly of January 1925, was later reprinted as a pamphlet. No one has ever admitted authorship, although in the opinion of Beatrice Webb Trevelyan was the probable author. See Beatrice Webb, Diaries (London, 1952-56), Il, p. 57.

${ }^{98}$ FA, May 1924, p. 217.

${ }^{99}$ Ibid., June, p. 243.

${ }_{100}$ Cutting from the Daily Telegraph, May 24, 1924, MP, F 7.

101 Ponsonby to Morel, May 24, 1924, MP, F 8. 
what Britain would do if Germany refused to accept the scheme, to which the Prime Minister responded irritably: "She must accept. We shall make her accept. We must have some settlement." The same source attributed this cutting retort to George Lansbury: "That is what Lloyd George used to tell us in 1919." 102 Shortly after the meeting, in a letter of April 12, MacDonald took Morel to task for the rigidity of his position and claimed that the Dawes Plan offered the only practicable way out of the reparations impasse. ${ }^{103}$

Support for the Dawes Plan clearly implied a reversal of previous Labour Party policy on reparations. The debate within the party was over whether this change constituted a betrayal of principles, or simply a recognition of the unavoidable. Taking the former view, Morel assumed leadership of what he termed "the revolt of the back benches". ${ }^{104}$ Most of his backing came from the ILP Parliamentary Group; even the insular Clydesiders, outraged by MacDonald's failure to implement socialist measures, warmed up to the issue. Through an impassioned message of July 31 , which was read to the group's meeting the next day, Morel warned of the likelihood that the government would ignore past party declarations that reparations be limited to the devastated areas of France and Belgium. ${ }^{105}$ The ILP'ers were sufficiently aroused to send the group's secretary, Fenner Brockway, to apprise the Prime Minister of their anti-Dawes sentiments; but MacDonald summarily dismissed him. ${ }^{106}$ Morel carried his campaign to the Labour press with his "Revolt of the Back Benches" letter to the New Leader of July 25 , a bald warning to the party leadership that there were men in the party who would fight against "the apparent jettisoning [. . .] of convictions and pledges which have been the inspiration of the Party for the last five years". ${ }^{107}$ In the House of Commons debate of July 14, he had stood up to challenge MacDonald by remarking on the incongruity of a British Labour government supporting a reparations policy, the effect of which was to cut into British exports and thereby increase unemployment. ${ }^{108}$

102 The Diplomacy of Mr. Ramsay MacDonald, op. cit., p. 11. It is not clear whether or not "U.D.C." actually witnessed this encounter, although he gives the impression that he did.

103 MacDonald to Morel, April 12, 1924, MP, F 8.

104 This was the title of his letter to the New Leader, July 25, 1924.

105 Morel to the ILP Parliamentary Group, July 31, 1924, MP, F 2.

106 A. Fenner Brockway, Inside the Left. Thirty Years of Platform, Press, Prison, and Parliament (London, 1942), p. 152.

107 New Leader, July 25, 1924, p. 5. MacDonald sent two long indignant letters to the journal protesting the publication of Morel's statement.

108 HCD, Vol. 176, c. 135. 
Grumbling similar to Morel's about the economic effects of the Dawes Plan could be heard among the party's rank and file. For example, the annual meeting of the Trades Union Congress in early September passed an anti-Dawes resolution by a large majority. ${ }^{109}$ There were identical complaints at the party's annual conference a month later; but there MacDonald's presence and the imminence of a general election prevented an open breach, as a motion to condemn the Dawes Plan failed to carry. ${ }^{110}$ By the time these Labour protests surfaced, however, Morel himself had made an incredible volte-face. His Foreign Affairs editorial of September waxed enthusiastic over the outcome of the London Conference, which had been held for the purpose of putting in train the details of the Dawes Plan. The conference he described as a personal success for MacDonald and "the first halt on the road to ruin since Versailles"; the plan itself, as interpreted by the London Agreement, he now regarded as substituting possible for impossible fulfilment, methods of justice for those of force. ${ }^{111}$ A turnabout of such dimensions is difficult to explain, although one might expect Morel to be pleased with some of the terms of the London Agreement, such as the floating of an international loan to help Germany get back on her feet and the promised end of the Ruhr occupation. In fact, he objected only to the conference's failure to fix a total, and reasonable, reparations sum. ${ }^{112}$

The war-guilt question and its treaty manifestation, the war-guilt clause, remained unexamined and unchanged. Nor had there been an abandonment of Britain's share of reparations. It was an act of almost Herculean self-control for Morel to remain silent on these issues, so central to his critique of the post-war settlement; yet he did so. In the light of the impending partisan battle over the Russian Treaty, in the negotiation of which he had played a significant role, he really had no choice but to rally round the party standard. It would be unseemly, to say the least, to carp against MacDonald in the Scottish constituency of Dundee for falling short of perfection in the Dawes negotiations. So when the Prime Minister visited Scotland in early September, Morel led the delegation of Labour notables greeting him at the Dundee railway station and praised him warmly as "the great peace minister". But MacDonald responded with a sneer, characterizing his critics in the party who had talked about "pledges

109 Richard W. Lyman, The First Labour Government 1924 (London, 1957), p. 165.

110 Report of the Twenty-Fourth Annual Conference, pp. 108, 141, 143-44.

111 FA, September 1924, p. 54.

112 Ibid. 
still to be fulfilled" and who had denounced him for faintheartedness as "foolish people, very foolish people". ${ }^{113}$

When Morel reached the point of an open break with MacDonald, it was over Russia, not Germany. The Prime Minister's fear of appearing proCommunist had made him indifferent to the success of negotiations with the Soviet government on the war debts, propaganda and fisheries controversies. Probably the negotiations would have collapsed completely without the intervention of a Morel-led group of Labour backbenchers who took it upon themselves to work out a face-saving formula on the debts question with the Soviet negotiators. ${ }^{114}$ The resultant draft treaty, however, soon became the most explosive issue in British politics, not so much because of its terms, which were limited enough, but because of the opportunity it offered the Conservative opposition to portray the government as the dupes of the Communists. When the Liberals took the same line and voted against the government, a general election ensued; not surprisingly, the "Red" issue monopolized the rhetoric of the Tory candidates and the headlines of the Tory press.

The bombshell of the 1924 election campaign was the so-called Zinoviev or Red Letter. ${ }^{115}$ On the eve of the ballot (October 28), Morel vented his rage against the Foreign Office professionals, long his bogey, for releasing what to him was obviously a forgery. To a man, he charged, Foreign Office personnel were anti-Labour and pro-Tory. They hated the present Russian government because it had exposed their secret diplomatic dealings with the Tsar, whereas on the home scene they feared the Labour Party for the threat it represented to vested interests, theirs in particular. ${ }^{116}$ But he was

113 Dundee Advertiser, September 9, 1924, pp. 3, 5. Morel had been warned of MacDonald's disposition by Ponsonby: "When you talk to JRM talk of anything you can think of that is not remotely connected with politics." Ponsonby to Morel, September 6, 1924, MP, F 8 .

114 For a full account of this intervention, the accuracy of which has never been challenged, see "How the Anglo-Russian Conference was Saved by the Labour Back Benches. Secret History of the Events of August 5, 6, 7, 1924", MP, F 2. An abridged version of this memorandum appeared in Forward (August 23, 1924) and in Foreign Affairs (September 1924).

115 For a full and interesting account of the Red Letter, see Lewis Chester, Stephen Fay and Hugo Young, The Zinoviev Letter (Philadelphia and New York, 1968).

${ }_{116}$ Dundee Advertiser, October 29, 1924, p. 5. Some days later J. L. Garvin in The Observer called Morel to task for criticizing the civil service, which could not legally respond, without evidence and purely for the sake of his own election campaign. In a reply published posthumously in Forward (November 15, 1924), Morel held that the release of the Red Letter was designed to torpedo Labour's election chances and had done so, adding that no act more disgraceful had occurred in any generation. He denied attacking the civil service, only the abuse of power behind the shield of civil-service immunity. 
also convinced that what he regarded as a conspiracy between the Tories and their despicable allies in Whitehall and Fleet Street could not have succeeded so well without the co-operation, however inadvertent, of the Prime Minister. The more he dwelled on the whole fiasco, in the aftermath of Labour's massive defeat, the more persuaded he became that MacDonald had blundered badly, first, by failing to assert control over his untrustworthy underlings at the Foreign Office, and second, by not consulting his political subordinates, especially Ponsonby. Equally regrettable was MacDonald's unwillingness, during his last days in office, to examine or publicize any of the pertinent details of the month of October. To George Lansbury, one of the more prominent Labourites involved in the backbencher intervention in the Anglo-Soviet negotiations, Morel declared that he wished to see MacDonald openly arraigned. Lansbury shared his opinion of the party leader but was less sure of a course of action. ${ }^{117}$

Morel's own highly successful re-election campaign and all of the events of the preceding months, which included a tour of Poland, had drained him thoroughly. He was physically spent and mentally depressed. A few days after his return from the hustings he unburdened himself in a long talk with Douglas Goldring; MacDonald's "shuffling" over his answer to the Red Letter, he told Goldring, was a "cowardly betrayal" of all the principles for which the UDC stood. ${ }^{118}$ In a conversation with his American friend, James G. McDonald, he blamed Labour's loss of seats on "mistakes of leadership". ${ }^{119}$ After so venting some of his frustration he left London for his rural retreat in Devonshire, where, on November 12, he died suddenly, aged fifty-one. In the opinion of Mrs Swanwick, his death saved the party from a rending internecine struggle. ${ }^{120}$ Indeed, there was such a struggle in 1925 over MacDonald's abandonment of treaty revisionism and the socialism of the party program, although it was less rending than it might have been. MacDonald retained the party's confidence, and even received widespread sympathy as the victim of an unfair and vicious election stunt.

Fighter, crusader, moral absolutist, extremist - all can be made to fit Morel; "his politics were his religion", observed Goldring. ${ }^{121}$ What was the nature of Morel's extremism, if extremist he was? The late Charles Loch

117 Draft letter to the New Leader, November 12, 1924, MP, F 7; Lansbury to Morel, November 10, F 9.

118 Goldring, The Nineteen Twenties, p. 161.

119 "Remarks by James G. McDonald at the Morel Memorial Meeting in Community Church, New York, January 25, 1925", MP, F 1.

120 Swanwick, I Have Been Young, op. cit., p. 422.

121 Goldring, ibid. 
Mowat, in Britain Between the Wars 1918-1940, mentioned him in passing as "an advanced Socialist". ${ }^{22}$ It seems likely that this erroneous estimate was the result of Mowat's reading of Morel's vigorously pro-Soviet statements. Certainly he was pro-Soviet, but not on ideological grounds. Rather, he sympathized with the Communist state as a victim of the victorious Allied reactionaties; and he also was deeply grateful to it for having published the secret treaties detailing the territorial horse-trading between Tsarist Russia and the British Foreign Office. In spite of his affiliation with the Labour Party, Morel remained what he had been before and during the war - a pacifist radical concentrating almost exclusively on foreign affairs. Few things annoyed him more, as an MP, than having to devote time to local labor disputes, bridge-building projects, and the like. Like many other radicals he had to have a cause, a mission in life; his was the education of the masses in the principles of true internationalism. The danger of their remaining unenlightened had been made manifest during the recent wartime period when the penny press, working at the behest of the country's ruling circles, had transformed their simple patriotism into a raving chauvinism. Morel's radicalism was extreme, if not his socialism. He hated the British political Establishment and was determined to expose what he regarded as its perversion of democracy in the area of foreign policy. There may have been a cutting social edge to his hatred, arising in part from his lack of a public-school and university background. Others with the same handicap, such as Lloyd George, often displayed a similar attitude.

Morel's self-proclaimed political antecedents were not Marx and Engels, or even William Morris and Keir Hardie, but Cobden and Bright. ${ }^{123}$ Some years ago A. J. P. Taylor defined a type in the English reform tradition which he termed the foreign-policy dissenter. Dissent over foreign policy, in Taylor's view, entailed not simply disagreement over details but moral protest. $^{124}$ This tradition started with Charles James Fox, and certainly included Cobden and Bright, who opposed the Crimean War as the excrescence of a misguided diplomacy which was not, but should be, controlled by Parliament. Half a century later Morel entered the ranks of the foreign-policy dissenters, his suspicions of the Foreign Office having been aroused by its less than straightforward behavior over the Congo. In terms of his political heritage, then, if not his paternity, he was a thoroughly English figure, strongly reminiscent of nineteenth-century evangelical

122 Charles Loch Mowat, Britain Between the Wars 1918-1940 (London, 1955), p. 145.

123 See, e.g., his Foreword in Swanwick's Builders of Peace.

124 Taylor, The Trouble Makers, op. cit. 
reformers (though without their formal religion). ${ }^{125} \mathrm{He}$ was a pacifist but a belligerent, highly politicized one, contemptuous of the "amiable respectabilities" leading the other pacifist organizations; they were too feeble, he believed, for the task of modern peace propaganda, a propaganda that must be "bold and aggressive - almost arrogant". ${ }^{26}$

Morel had his greatest influence among left-wing intellectuals and Labour Party activists. Yet heterodoxies that he advanced in the early twenties, such as the claim that the war had not been caused by deliberate German aggression, had become orthodoxies by the thirties. By then too, most Britons believed that Germany had legitimate grievances arising out of the Versailles Treaty. One historian, Robert E. Dowse, holds the exradicals in the UDC set ultimately responsible for the debacle of Munich. "From within the I.L.P.", Dowse alleges, "their ideas soon permeated the British national consciousness and culminated in the piece of paper brandished by Neville Chamberlain."127 Morel's writings did figure in the arguments of one arch-appeaser, William Sackville Russell, Duke of Bedford. The Duke paraded Morel's views on the origins of World War I and his predictions of a future war if the Versailles Treaty went unrevised, and then proclaimed what he regarded as the contemporary application of Morelism - that Germany was not solely responsible for World War II either. Poland, he professed to believe, would have accepted the "reasonable" German proposals on border rectification of March 1939 if not for British prompting against doing so. ${ }^{128}$ All the same, one can argue, as Martin Gilbert does, that Munich was not true appeasement, but a perversion of it under the impetus of fear. ${ }^{129}$ Appeasement directed towards the satisfaction of Germany's just grievances through concessions, in Gilbert's words, was "a search for international relations conducted without resort to armed conflict", "a search for methods to resolve national grievances without stirring up hatred and fear". ${ }^{130}$ Morel and the UDC obviously helped to disseminate these views. But from the beginning of the inter-war period, appeasement was not restricted to any one man or small

125 His mother's Quaker background may have had much to do with this.

126 "What Should the UDC Do Next?" (1924), p. 1, MP, F 6. The relationship between the UDC and specifically pacifist organizations was not close. Although Trevelyan was a co-founder and chairman of the National Peace Council, a coalition of groups which included the UDC, UDC representatives usually failed to attend its meetings.

127 Robert E. Dowse, “The Independent Labour Party and Foreign Politics 1918-1923”, in: International Review of Social History, VII (1962), p. 46.

128 The Duke of Bedford, Diplomacy and War Guilt. A tribute to the Vision and Peace Aims of the late E. D. Morel MP (Glasgow, 1941), pp. 3-15.

129 Martin Gilbert, The Roots of Appeasement (London, 1966), p. 179.

130 Ibid., p. 159. 
group - it included every single British prime minister to a greater or lesser degree! ${ }^{131}$

Morel grasped, as few others did, the disastrous psychological reaction of the German people to the peace treaty and to the Allied attempts to enforce it. ${ }^{132}$ Whether he would have excused Hitler, the chief beneficiary of that reaction, is impossible to say. Advocates of treaty revision in the early post-war years did not necessarily become apologists for Nazi Germany. Possibly his moral sense would have been outraged, as it was by Mussolini's brutality; this was the case, for example, with Charles P. Trevelyan, who argued against the Baldwin government's policy of nonintervention in the Spanish Civil War and in favor of collective-security agreements against fascist aggression. On the other hand, Charles Roden Buxton urged greater territorial concessions to Hitler than Chamberlain would actually grant at Munich. Leonard Woolf observed of Buxton: "The Versailles Treaty made him what was called a pro-German in the grim years of peace, and I do not think that in the 1930's, when Hitler and the Nazis came to power, he could bring himself to face the facts and the terrible menace of war and barbarism from Germany." 133 The UDC itself was militantly anti-fascist; in fact, the 1930's constituted a period of vitality for the organization second only to the Morel years. ${ }^{134}$ During the Second World War it maintained substantial contacts with anti-Nazi resistance movements in Europe, and after the war it opposed nuclear weapons, German rearmament, and the continuation of Western colonial controls in Africa and Asia. Finally, in 1966, after fifty-two years of existence, the UDC expired for lack of support. ${ }^{135}$

\footnotetext{
131 Ibid., pp. 54-55.

132 See, e.g., Hobson, Confessions of an Economic Heretic, p. 114. In Hobson's view, few foreign observers had any notion of this.

133 Leonard Woolf, Downhill All the Way. An Autobiography of the Years 1919-1939 (London, 1967), p. 245.

134 Interview with Professor John Saville, Hull University, March 8, 1973.

135 C. R. Sweetingham to the author, September 20, 1972. Sweetingham was the last secretary of the UDC.
} 